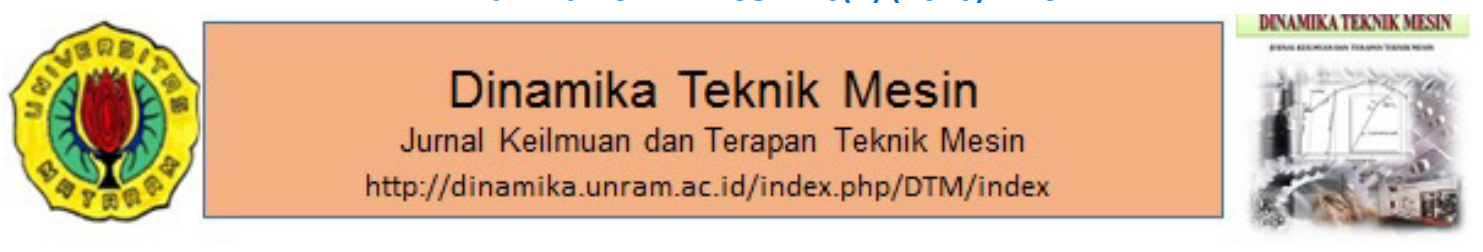

\title{
Effect of motorcycle exhaust pipe temperature and electrical circuit on harvested dc power from thermoelectric generators
}

\author{
M. Mirmanto*, H.S. Tira, A. Pabriansyah \\ ${ }^{1} J u r u s a n$ Teknik Mesin, Fakultas Teknik, Universitas Mataram, Jl. Majapahit no. 62, Mataram, NTB, \\ 83125, Indonesia. HP. 082111738971 \\ *Email:m.mimrnato@unram.ac.id
}

\begin{abstract}
ARTICLE INFO
ABSTRACT

Article History:

Received 03 August 2019

Accepted 27 October 2019

Available online 1 April 2020

Keywords:

Circuit

DC power

Thermoelectric

An experimental investigation to know the effect of temperatures and the electrical circuit was performed. Three identical thermoelectric generators model TEMOD-5W5V-35S were used in this investigation. To generate different high temperatures the motorcycle was run at $1600 \mathrm{rpm}, 2100 \mathrm{rpm}, 3100 \mathrm{rpm}$. The circuits examined were series, parallel and combination of the two. The loads used in the current measurements were a thermoelectric cooler module model SP1848 and a fan with a voltage of $12 \mathrm{~V}$ and a current of $0.13 \mathrm{~A}$. Those two loads were installed in a parallel circuit. The results showed that the tests without load produce the highest voltage, while the tests with the load result in the highest power. Increasing the temperature difference increased the power, and the parallel circuit resulted in the biggest power but the lowest voltage. The highest voltage of 3.3 $V$ was attained using the series circuit, while the highest power of $0.133 \mathrm{~W}$ was obtained using a parallel circuit.
\end{abstract}

\section{INTRODUCTION}

The need for energy consumption from time to time increases, especially the need for electrical energy. Technological advances in the utilization of semiconductor components produce renewable energy, i.e. electricity. One of the semiconductor technology is heat conversion technology into electricity using a thermoelectric generator. The thermoelectric generator can convert waste heat into DC electrical energy, Ding et al. (2017), Tang et al. (2017), Remeli et al. (2015). This technology is one of the green technologies needed as an alternative energy source for the future. In addition, this technology has several advantages: reliable durability, no sound when operated, easy maintenance, simple, compact and safe, lightweight, environmentally friendly, and a source of flexible energy. The basic principle of a thermoelectric generator is to utilize a temperature difference between the cold side and the hot side.

Thermoelectric generator researches utilizing waste hate have been developed rapidly. Ding et al. (2017) performed an investigation of generating electrical power using waste heat from the use of 
Dinamika Teknik Mesin. Mirmanto et al.: Effect of motorcycle exhaust pipe temperature and electrical circuit on harvested dc power from thermoelectric generators

natural gas water heater. They used 60 TECs and hot water as the heat source. The hot water temperatures employed were $50^{\circ} \mathrm{C}$ to $100^{\circ} \mathrm{C}$. They found the output maximum power of $42.4 \mathrm{~W}$. Previously; Remeli et al. (2015) used waste hate to generate power. However, they used heaters and fans for their experiments to generate and flow the heat. Furthermore, to transfer the heat they used heat pipes and the thermoelectric was placed between the two heat pipes. Using eight TEG (thermoelectric generator) modules generated the maximum power of approximately $6.9 \mathrm{~W}$. If this result is compared to that of Ding et al. (2017), this result is higher. However, the method used by Remeli et al. (2015) is more complicated. Recently, Tang et al. (2017) used waste heat from automotive mobility. They employed 6 TEG modules and they found the maximum power of $15.86 \mathrm{~W}$ at the rotation of $3200 \mathrm{rpm}$. This is much higher power compared to that of Ding et al. (2017) and Remeli et al. (2015). However, in this research, they used temperature up to $350^{\circ} \mathrm{C}$. The cold side of the TEG was cooled using water from the engine cooling system with a temperature of around $90^{\circ} \mathrm{C}$ when the engine was running.

Another waste of hate that can be utilized is heat from asphalt. Aprianus et al. (2011) performed research on alternative electric harvest by utilizing thermoelectric technology mounted on road asphalt. Because the absorption of solar energy is quite effective, asphalt has a high temperature as well. This high temperature can be used to generate electricity using TEG. They obtained that in the period of 1 hour, the thermoelectric could generate a voltage of about 3.51 volt with a temperature difference between asphalt and soil ranging from $26.9^{\circ} \mathrm{C}$ to $38.0^{\circ} \mathrm{C}$. Sugiyanto and Siswantoro (2014) examined the utilization of heat on LPG gas stoves for power generation using thermoelectric generators. Maximum current and voltage obtained were $4.17 \mathrm{~V}$ and $0.48 \mathrm{~A}$ or $2 \mathrm{~W}$. Sugiyanto et al. (2015) conducted a study on the design of TEG construction on motorcycle exhaust for independent power generation. The thermoelectrics was installed right on the head pipe so they could get high temperature. However, the resulting voltage was only about $0.67 \mathrm{~V}$. The lower voltage can be due to the small temperature difference. Usually, when the hot side is attached to the high-temperature source, the cold side temperature also increases sharply due to the insufficient cooling system on the cold side. Therefore, in this current study, the thermoelectric is installed far down to the end of the exhaust pipe and the cold side of the TEG is cooled using a heat sink fin-fan. With this method, converting waste hate from the motorcycle exhaust pipe to be electrical power increases. This method also indicates a new thing in the field of studies.

\section{RESERACH METHOD}

The schematic diagram of the experimental apparatus is shown in figure 1, while the construction of the TEG is indicated in figure 2. The test rig (figure 1a) consists of three TEGs model TE-MOD-5W5V-35S with specifications shown in table 1, an exhaust pipe, one TEC model SP1848 as a load, fan $12 \mathrm{v}-0.13 \mathrm{~A}$ as a load, three fans for cooling the cold side of the TEG. The TEGS were arranged in parallel, series and mix circuits, while the motor was run at $1600 \mathrm{rpm}, 2100 \mathrm{rpm}, 3100$ rpm. Additional tests were also conducted to have higher experimental hot side temperatures. The additional tests were performed using a heater with the maximum temperature applied or set of $165^{\circ} \mathrm{C}$. All temperatures were measured using calibrated K-type thermocouples with an uncertainty of \pm $0.5^{\circ} \mathrm{C}$. The current and voltage were assessed using a digital multitester (model Professional Vichy Vc8145). The circuits employed were parallel, series and mix as shown in figure 3.

The TEG installation in this study is different from that of Sugiyanto et al. (2015). In this study, the TEGs were installed at the end of the exhaust pipe, while that of Sugiyanto et al. (2015) was installed exactly at the exhaust head pipe. Moreover, for additional tests using a heater, the circuits used were the same but the tests were not conducted on the motorcycle. All TEGs were placed on the top of an aluminum plate with a thickness of $10 \mathrm{~mm}$. The heater was inserted into a hole in the aluminum plate with a diameter of $7 \mathrm{~mm}$. The heater power used was approximately $250 \mathrm{~W}$, and the heater temperature was controlled using a PID. 
Dinamika Teknik Mesin. Mirmanto et al.: Effect of motorcycle exhaust pipe temperature and electrical circuit on harvested dc power from thermoelectric generators

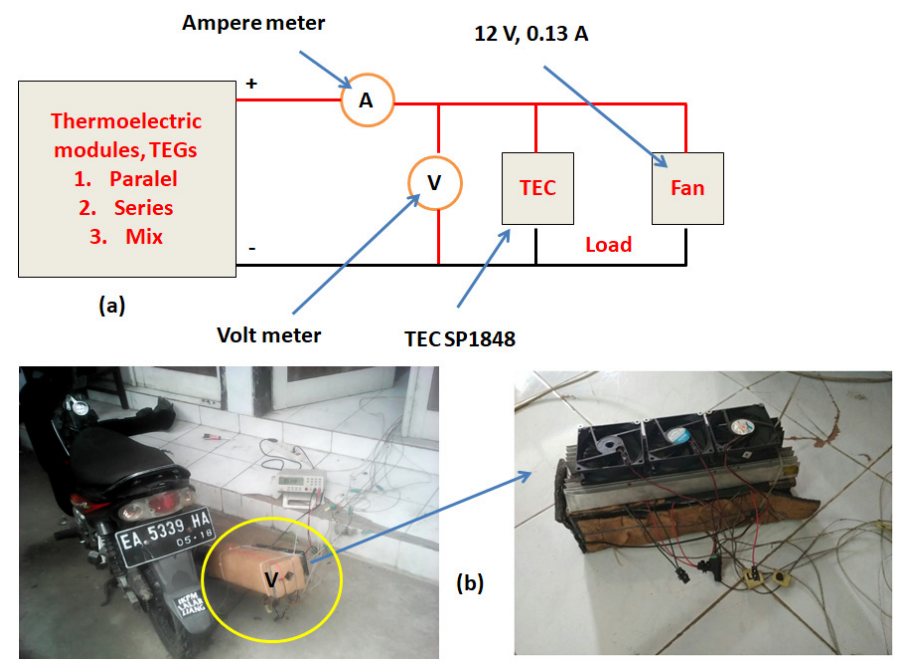

Figure 1. Experimental facility: (a) schematic diagram, (b) TEG assembly photograph, TEG stands for thermoelectric generator

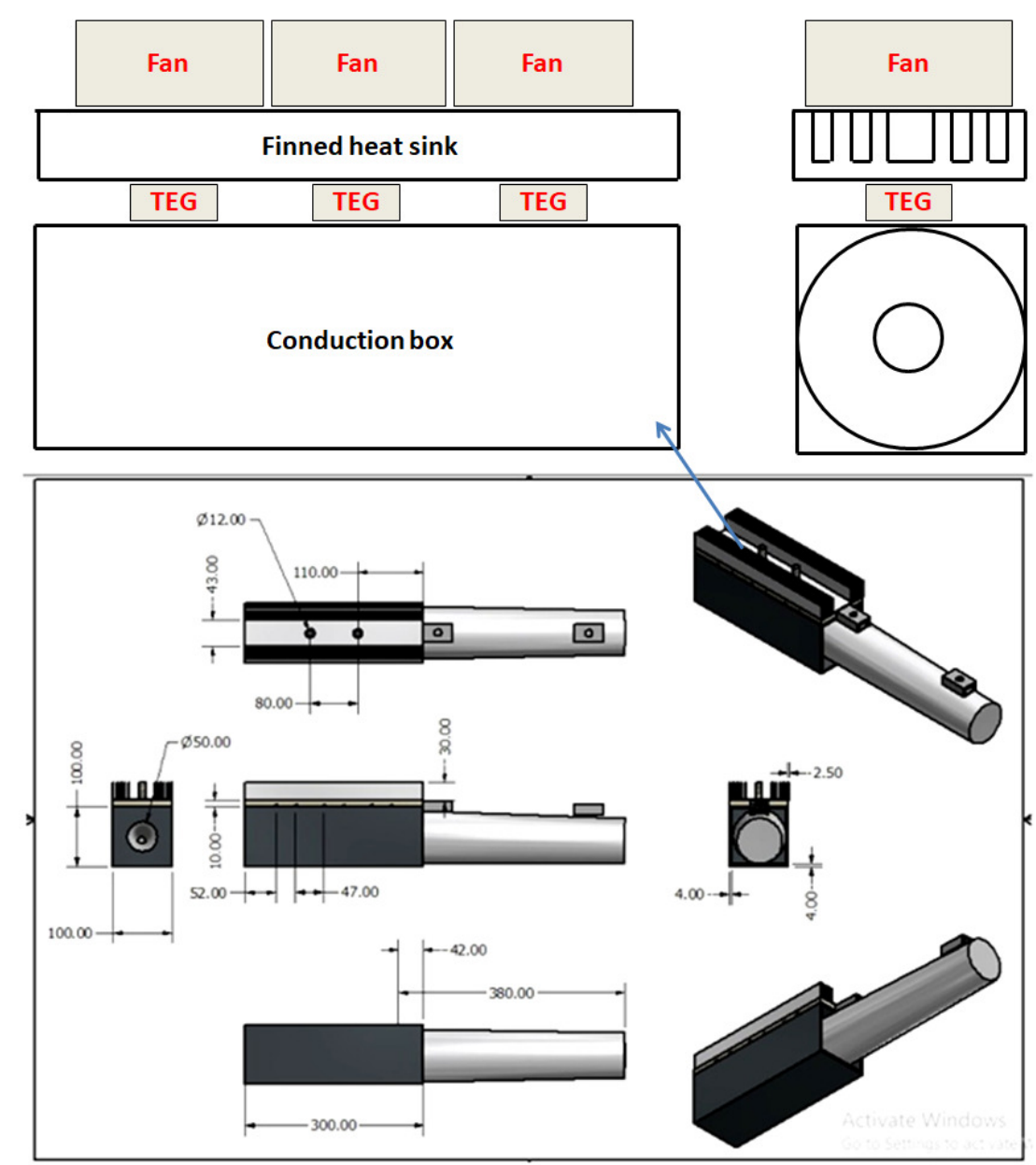

Figure 2. TEG construction and conduction box dimension 
Dinamika Teknik Mesin. Mirmanto et al.: Effect of motorcycle exhaust pipe temperature and electrical circuit on harvested dc power from thermoelectric generators

To increase the temperature of the exhaust pipe, the rotation of the engine was elevated. The rotations of engine employed were $1600 \mathrm{rpm}, 2100 \mathrm{rpm}$, and $3100 \mathrm{rpm}$. Meanwhile, the temperature of the aluminum plate for the experiments without an engine was adjusted using PID. The temperatures set were $65,80,110,145$, and $165^{\circ} \mathrm{C}$. However, to resist the increase in temperature of the cold side of the TEG, heat sinks with fans were installed.

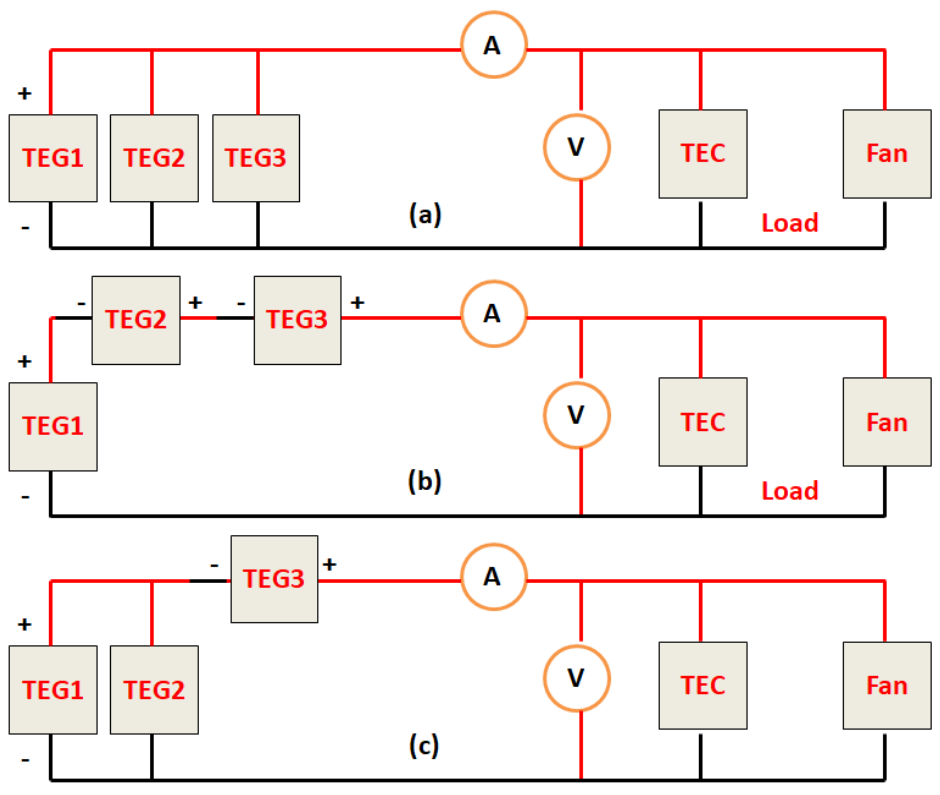

Figure 3. Circuits used in the study: (a) parallel, (b) series, and (c) mix

\section{RESULTS AND DISCUSSION}

Temperatures recorded at the cold and hot sides as well as at the exhaust pipe are presented in Figure 4. Increasing the engine rotation increases the cold side, hot side, and exhaust pipe temperatures. This finding was also found by Tang et al. (2017). However, they detected the increased temperature of exhaust gas. Increasing engine rotation increased the exhaust gas temperature. Nevertheless, in the current study, the cold side temperature was not able to be kept at the same value (constant) for all engine rotations. Figure 4(b) shows temperatures obtained from experiments using a heater. Similarly, the cold side temperatures were also not constant. Increasing the PID temperature setting increases the hot and cold side temperatures. This indicates that the cooling system (heat sink and fans) is insufficient to remove the heat from the cold side. Increasing the hot side temperature of the TEG elevates the conduction heat transfer from the hot side to the cold side. Meanwhile, the heat sink and fans have achieved the maximum heat that can be removed, consequently the cold side temperature increases. This also agrees with the thermal equilibrium for TEG, Jugsujinda et al. (2011).

$Q_{h}=Q_{c}+P$

$Q_{h}$ is the heat given to the hot side (W). To increase $Q_{h}, T_{h}$ should be increased. $T_{h}$ is the hot side temperature $\left({ }^{\circ} \mathrm{C}\right) . Q_{c}$ is the heat that should be removed from the cold side $(\mathrm{W}) . Q_{c}$ corresponds to $T_{c}$. $T_{c}$ is the cold side temperature $\left({ }^{\circ} \mathrm{C}\right)$. When $Q_{c}$ is low, then $T_{c}$ increases and vice versa. $P$ is the electrical DC power that resulted in the TEG (W). This power can be estimated using equation (2), however, this power depends on the temperature difference between the cold and hot sides of the TEG. In a cooling system, $Q_{h}$ is the heat that should be pumped away from the thermoelectric, while $Q_{c}$ is the heat that is absorbed by the cold side of the thermoelectric. Therefore, for this study, the direction of the heat flow is different from that in the cooling system. Equation (1) was also used by several previous researchers, especially for cooling system researchers, e.g. Jugsujinda et al. (2011), Ananta et al. (2017), Mirmanto et al. (2018). They all used the equation (1) for cooling system studies though. 
Dinamika Teknik Mesin. Mirmanto et al.: Effect of motorcycle exhaust pipe temperature and electrical circuit on harvested dc power from thermoelectric generators

$$
P=V I
$$

$V$ is the voltage coming out from the TEG $(\mathrm{V})$ and $I$ is the current flowing out from the TEG (A). In a cooling system, $P$ is the DC electrical power given to the TEC (thermoelectric cooling). The equation (2) was taken from Jugsujinda et al. (2011), Ananta et al. (2017), Mirmanto et al. (2018) for their cooling system researches.
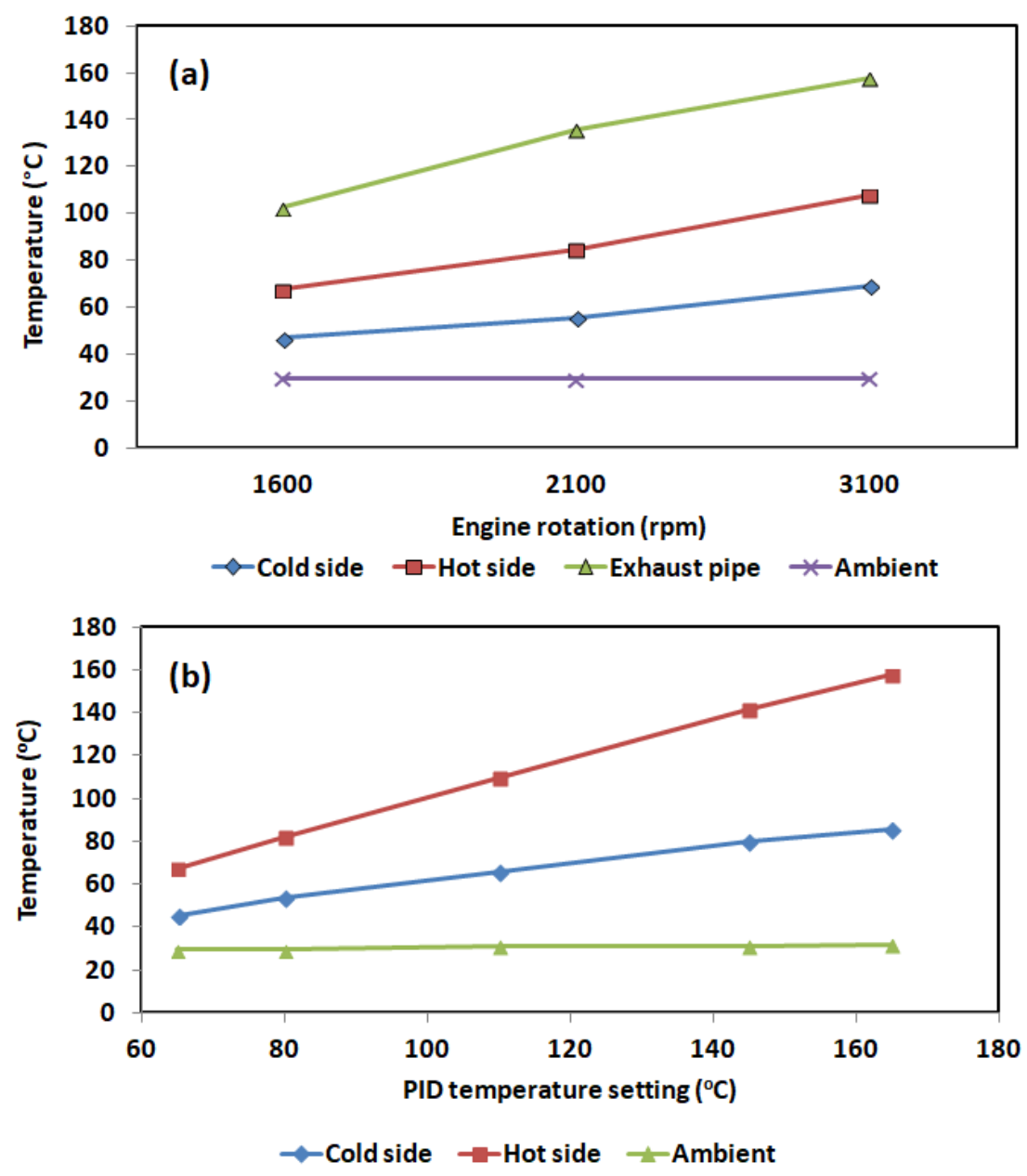

Figure 4. Temperatures recorded obtained from (a) experiments using a motorcycle exhaust pipe, (b) experiments using a heater

The voltage and current resulted in the TEG depend on the temperature difference, Suryanto et al. (2017). The experimental temperature differences are presented in figure 5 . Increasing the rotation of the engine increases the hot side temperature, consequently the temperature difference increases. Similarly, the temperature differences obtained for the additional tests also increases with the increased PID temperature setting. The hot side temperature increases, the cold side temperature also increases, however, the increased cold side temperature is not linear with the increased hot side temperature. Consequently, the temperature difference increases. At every different engine rotation results in the different hot side and cold side temperatures, surely, the temperature difference is also various.

Due to temperature differences, the TEG produces voltages and currents. When there is no load, the TEG just produces voltages, but not currents. Increasing the temperature difference elevates the voltage and the current productions. This was also found by Paraskevas and Koutroulis (2016), Suryanto et al. (2017). 
Dinamika Teknik Mesin. Mirmanto et al.: Effect of motorcycle exhaust pipe temperature and electrical circuit on harvested dc power from thermoelectric generators
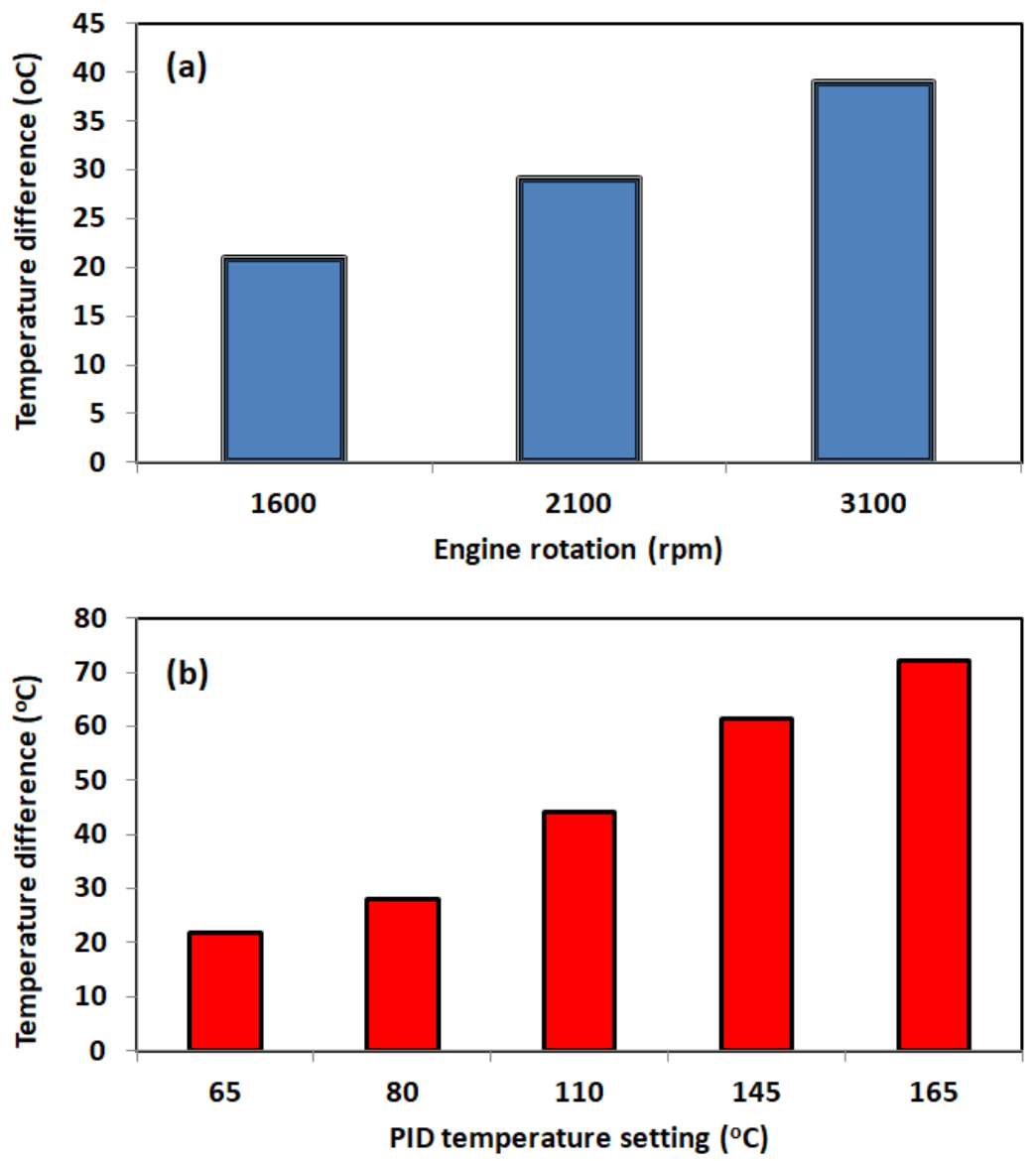

Figure 5. Temperature differences obtained from experiments using; (a) motorcycle exhaust pipe, (b) heater

As mentioned in the previous paragraph, the harvested DC power depends on the temperature, especially the temperature difference between the cold side and hot side of the TEG. Increasing the temperature difference elevates the output voltage as shown in figure 6 . This is due to the relationship between the cold side and hot side temperatures as indicated by equation (3), which can be found in the previously published study, e.g. Sugiyanto and Siswantoro (2015), Monteccuco et al. (2014).

$V=\alpha\left(T_{h}-T_{c}\right)$

$V$ is the voltage $(\mathrm{V}), \alpha$ indicates the Seebeck effect $\left(\mathrm{V} /{ }^{\circ} \mathrm{C}\right)$, while $T_{h}$ and $T_{c}$ are the hot and cold side temperatures. Meanwhile, $T_{h}-T_{c}$ is the temperature difference $\left({ }^{\circ} \mathrm{C}\right)$.

Similarly, the current increases with the temperature difference as presented in figure $7(\mathrm{a})$. As the voltage and the current increase with the temperature difference, so that the power also raises with the temperature difference. This relationship is shown in Figure 7(b). Note that the power in figure 7 (b) is calculated using equation (2), while the current and the voltage are measured directly in the experiments. 
Dinamika Teknik Mesin. Mirmanto et al.: Effect of motorcycle exhaust pipe temperature and electrical circuit on harvested dc power from thermoelectric generators

One of the objectives of the study is to know the effect of the electrical circuit on the TEG power obtained. As shown in figure 3, there are three different circuits that are used: parallel, series and mix. Based on the theory, the series circuit generates higher voltages as the total voltage is equal to the sum of all prevailing voltages, as written in equation (4).
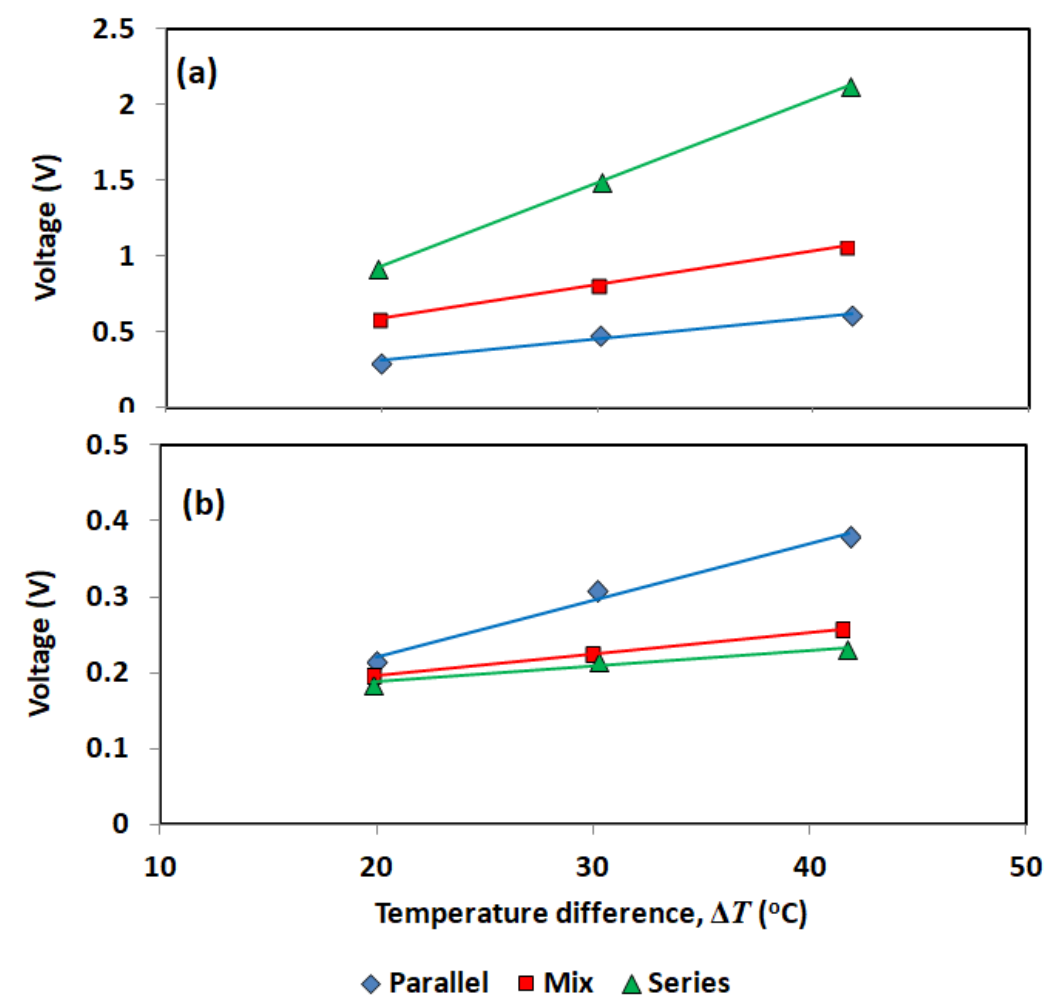

Figure 6. Relationship of voltage and temperature difference obtained from experiments using motorcycle exhaust pipe; (a) no-load, (b) with loads.

$V=V_{1}+V_{2}+V_{3}$

$V_{1}, V_{2}$, and $V_{3}$ are voltages resulted from each TEG, see figure $3(\mathrm{~b})$. However, $l_{1}, l_{2}$, and $l_{3}$ are the same in the series circuit. Due to the series circuit, the voltage obtained is always higher than the other two circuits, e.g. parallel, mix, see figure 6 . In contrast, the parallel circuit results in the lowest voltage. While the mixing circuit produces voltage values between the series and parallel circuits. For the parallel circuit, the voltage can be estimated as

$V=V_{1}=V_{2}=V_{3}$

For the mixing circuit, the equation that can be used is

$V=V_{1}+V_{3}$ or

$V=V_{2}+V_{3}$

Nevertheless, in this study, the measured voltage is the total voltage and the measured current is the total current. Equations (4) to (6) were taken from Ramdhani (2005). The total voltage and current are measured directly.

Opposite to the voltage, the current value of the series circuit is the lowest one, while the parallel circuit results in the biggest current. The mixing circuit produces current values between the parallel and the series circuits as shown in figure 7. However, increasing the current of voltage does 
Dinamika Teknik Mesin. Mirmanto et al.: Effect of motorcycle exhaust pipe temperature and electrical circuit on harvested dc power from thermoelectric generators

not always increase power. The power obtained using the parallel is higher than that of the two other circuits. This is due to the increase in the voltage and the decrease in the current. The mix circuit results in the lowest power. Similarly, the voltage, current, and power obtained from experiments using heater show the same phenomena, as shown in figure 8 . However, in figure 8 , the additional experiment is also presented and the temperature tested reaches $157.4^{\circ} \mathrm{C}$ (hot side temperature) resulting in $3.3 \mathrm{~V}$ without loads. The experimental currents and power obtained from experiments using a heater are given in figure 9.

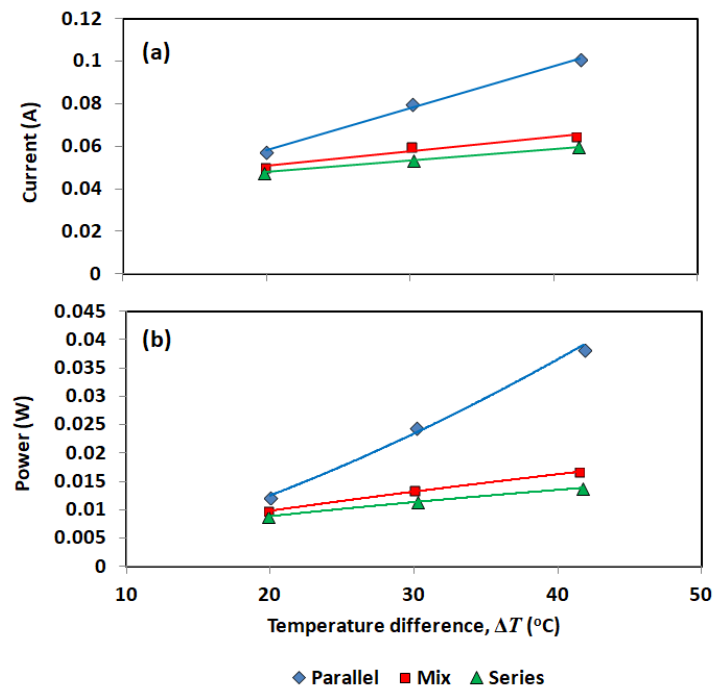

Figure 7. Relationship of current, power and temperature difference between three different circuits; (a) current, (b) power. These data are obtained from the motorcycle exhaust pipe with loads.

Similar to the results obtained using exhaust pipe, experiments using the heater also results in the increased voltage and current with the temperature differences. While the effect of the circuit on the voltage, current, and power is also clear. The voltages produced by the parallel circuit seem lower than those obtained by the two other circuits. However, the currents produced using the parallel circuit is higher than that of the two other circuits, as shown in figure 9. The last parameter examined is power. The power increases with the temperature difference as mentioned in the previous paragraph, but the trend of the power lines is not linear. The power follows the power trend line that can be constructed using Excel software. However, the power trends presented in figure 7 are close to the linear lines. This can be due to the insufficient point to construct the lines.

For both experiments using motorcycle and heater result in lower power. This was also found by Abidin et al. (2018). They explained the lower power was due to the thermoelectric module type, however, they stated that their experiments were visible for the future. In this study, the low power is due to the small temperature difference. As shown in Figure 9, the power increases following the power trend line. This indicates that when the temperature difference increases to higher values, the power obtained is high enough. This also shows that power is visible for the future as the power can be attained from renewable energy sources. All equations below were taken from Ramdhani (2005).

$V=V_{1}+V_{2}+V_{3}$

$V_{1}, V_{2}$, and $V_{3}$ are voltages resulted from each TEG, see figure $3(\mathrm{~b})$. However, $I_{1}, I_{2}$, and $l_{3}$ are the same in the series circuit. Due to the series circuit, the voltage obtained is always higher than the other two circuits, e.g. parallel, mix, see figure 6. In contrast, the parallel circuit results in the lowest voltage. While the mixing circuit produces voltage values between the series and parallel circuits. For the parallel circuit, the voltage can be estimated as 
Dinamika Teknik Mesin. Mirmanto et al.: Effect of motorcycle exhaust pipe temperature and electrical circuit on harvested dc power from thermoelectric generators

$V=V_{1}=V_{2}=V_{3}$

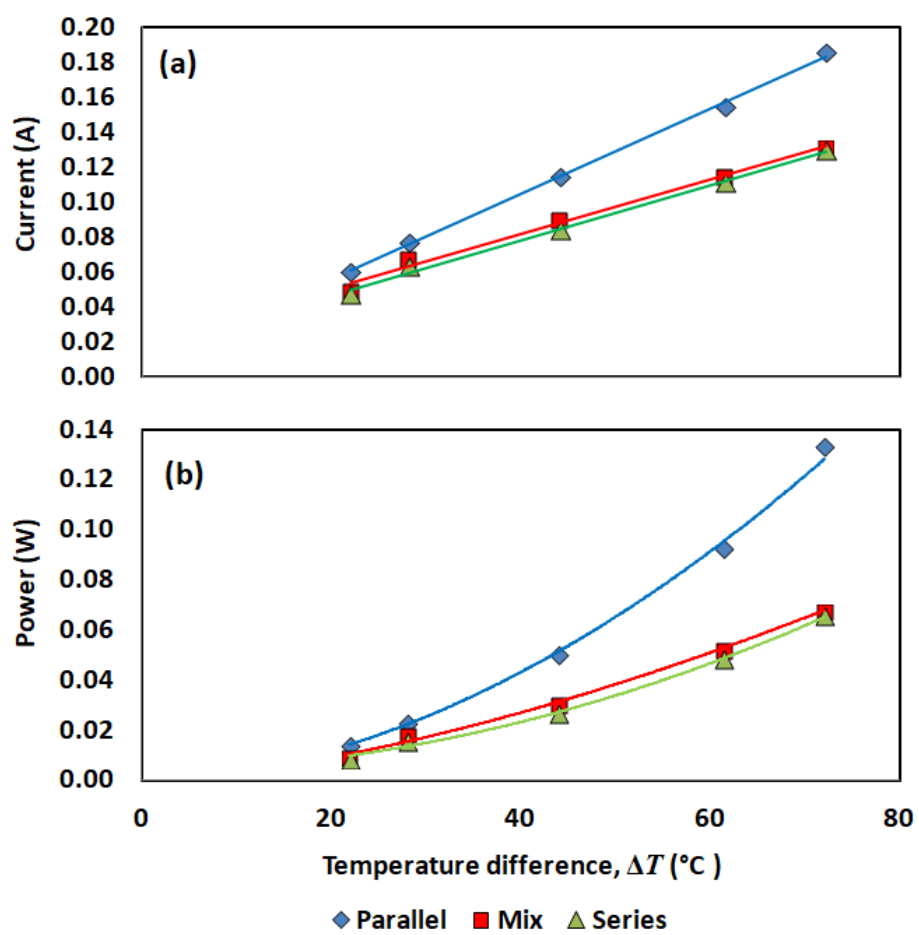

Figure 9. Relationship of the temperature difference and; (a) current, (b) power, obtained from the experiments using a heater

For the mixing circuit, the equation that can be used is

$V=V_{1}+V_{3}$ or

$V=V_{2}+V_{3}$

Nevertheless, in this study, the voltage and current is the total voltage and current, but not the individual voltage and current, hence, equations (4) to (6) were taken from Ramdhani (2005). The total voltage and current are measured directly.

Opposite to the voltage, the current value of the series circuit is the lowest one, while the parallel circuit results in the biggest current. The mixing circuit produces current values between the parallel and the series circuits as shown in figure 7. However, increasing the current of voltage does not always increase power. The power obtained using the parallel is higher than that of the two other circuits. This is due to the increase in the voltage and the decrease in the current. The mix circuit results in the lowest power. Similarly, the voltage, current, and power obtained from experiments using heater show the same phenomena, as shown in figure 8 . However, in figure 8 , the additional experiment is also presented and the temperature tested reaches $157.4^{\circ} \mathrm{C}$ (hot side temperature) resulting in $3.3 \mathrm{~V}$ without loads. The experimental currents and power obtained from experiments using a heater are given in figure 9. 
Dinamika Teknik Mesin. Mirmanto et al.: Effect of motorcycle exhaust pipe temperature and electrical circuit on harvested dc power from thermoelectric generators

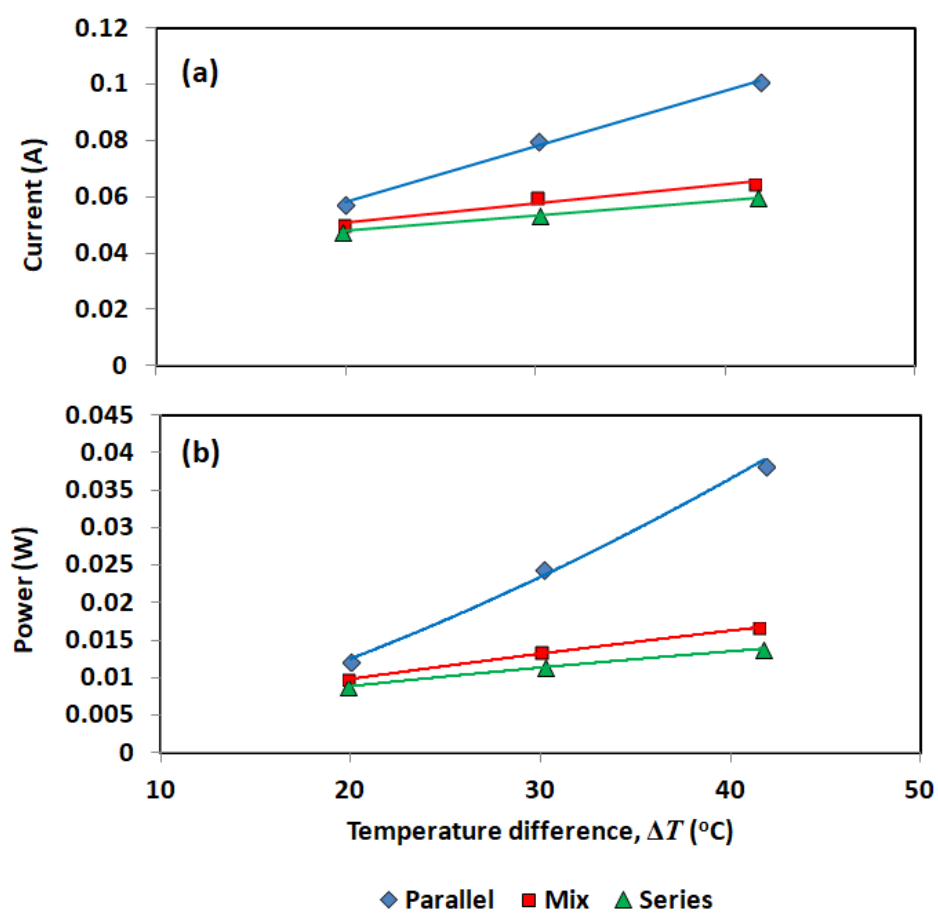

Figure 7. Relationship of current, power and temperature difference between three different circuits; (a) current, (b) power. These data are obtained from the motorcycle exhaust pipe with loads.

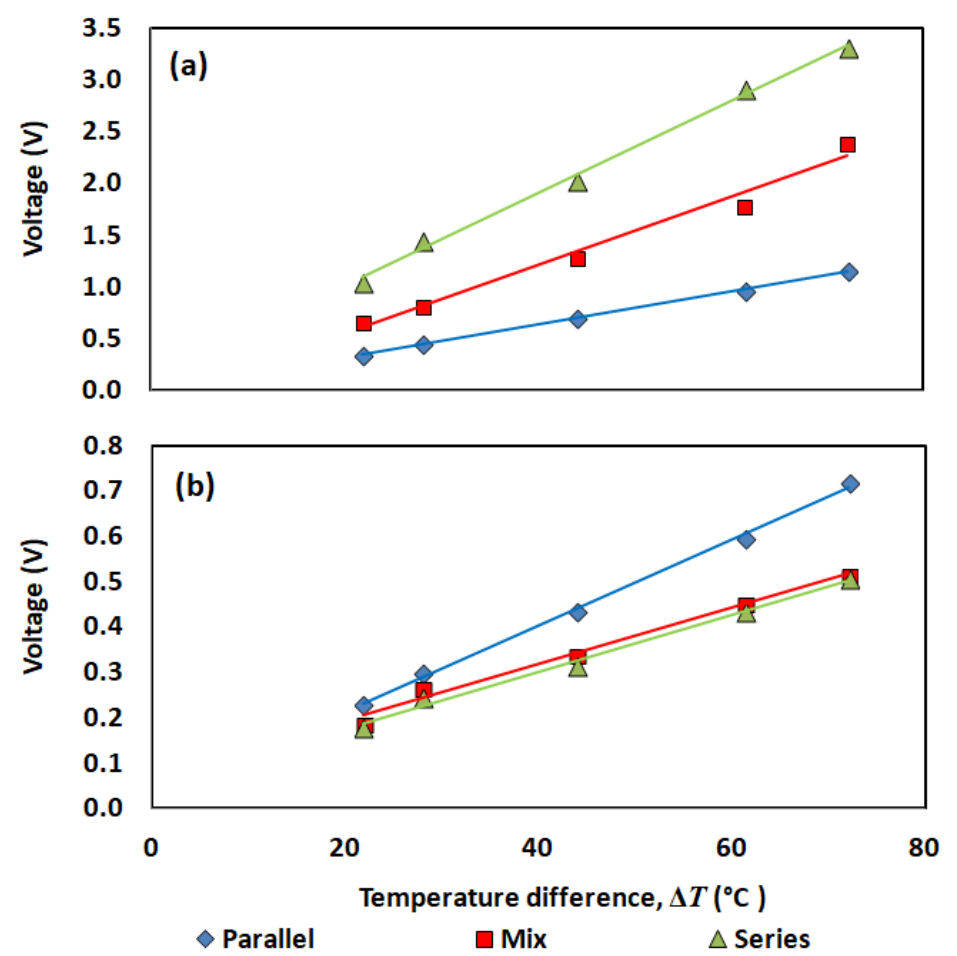

Figure 8. Relationship of temperature difference and voltages obtained from experiments using a heater; (a) no-load, (b) with loads

Similar to the results obtained using exhaust pipe, experiments using the heater also results in the increased voltage and current with the temperature differences. While the effect of the circuit on 
Dinamika Teknik Mesin. Mirmanto et al.: Effect of motorcycle exhaust pipe temperature and electrical circuit on harvested dc power from thermoelectric generators

the voltage, current, and power is also clear. The voltages produced by the parallel circuit seem lower than those obtained by the two other circuits. However, the currents produced using the parallel circuit is higher than that of the two other circuits, as shown in figure 9. The last parameter examined is power. The power increases with the temperature difference as mentioned in the previous paragraph, but the trend of the power lines is not linear. The power follows the power trend line that can be constructed using Excel software. However, the power trends presented in figure 7 are close to the linear lines.
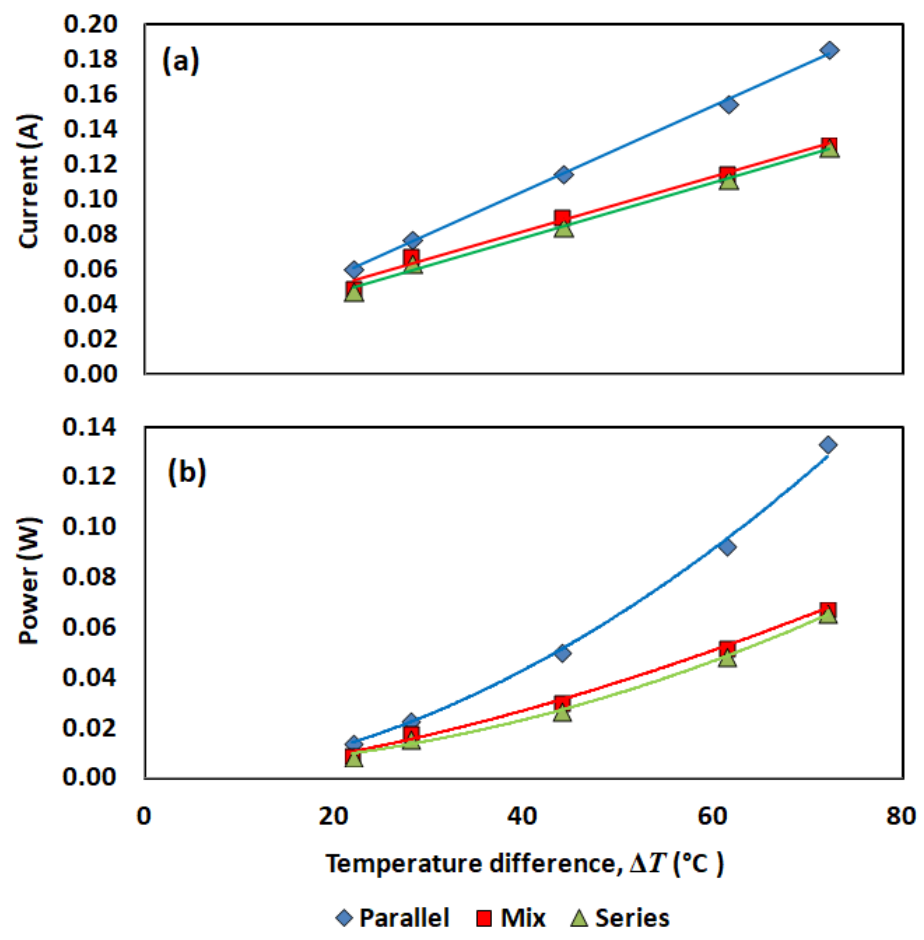

Figure 9. Relationship of the temperature difference and; (a) current, (b) power, obtained from the experiments using a heater

For both experiments using motorcycle and heater result in lower power. This was also found by Abidin et al. (2018). They explained the lower power was due to the thermoelectric module type, however, they stated that their experiments were visible for the future. In this study, the low power is due to the small temperature difference. As shown in figure 9, the power increases following the power trend line. This indicates that when the temperature difference increases to higher values, the power obtained is high enough. This also shows that power is visible for the future as the power can be attained from renewable energy sources.

\section{CONCLUSION}

Experiments to know the effect of exhaust pipe temperature and circuit on the harvested DC power have been conducted and from the experimental results and discussion, some findings can be given as follows:

1. The voltage, current and power increase with the increase in the temperature difference.

2. The parallel circuit results in the highest current, but in the lowest voltage.

3. The parallel circuit produces the highest power.

4. It is recommended to use a parallel circuit when the power is the important variable required, while the series circuit is recommended when the high voltage is required. 
Dinamika Teknik Mesin. Mirmanto et al.: Effect of motorcycle exhaust pipe temperature and electrical circuit on harvested dc power from thermoelectric generators

\section{ACKNOWLEDGMENTS}

The authors would like to acknowledge the Mechanical Engineering Department, Mataram University for the facility, and people that cannot be mentioned who have help in conducting the experiment and constructing the manuscript.

\section{REFERENCES}

Abidin S.Z., Bahrin S.K., Jaafar S., 2018, Initial development of an electrical power generator by using the thermoelectric generator, focal lens and underground heat dissipation system, International Journal of Electrical and Computer Engineering (IJECE), 8(4), 2549-2556.

Ananta H., Padang Y.A. Mirmanto, 2017, Unjuk kerja kulkas termoelektrik dengan rangkaian seri dan paralel pada beban air $1500 \mathrm{ml}$, Dinamika Teknik Mesin, 7(2), 80-86.

Aprianus M.B., Rivaldo H.S., Priskila A., Wahyu K., Setiawan A., 2011, Panen energi listrik alternatif dengan memanfaatkan teknologi termoelektrik pada aspal jalan raya, Jurnal Program Kreatifitas Mahasiswa, Fakultas Sain dan Matematika, Universitas Kristen Setyawacana.

Ding L.C., Meyerheinrich N., Tan L., 2017, Thermoelectric power generation from waste heat of natural gas water heater, Energy Procedia, 110, 32-37.

Jugsujinda S., Vora-ud A., Seetawan T., 2011, Analyzing of thermoelectric refrigerator performance, Procedia Engineering, 8, 154-159.

Mirmanto, Alit I.B., Sayoga I.M.A., Sutanto R., Nurchayati, Mulyanto A., 2018, Experimental cooler box performance using two different heat removal units: a heat sink fin-fan, and a double fan heat pipe, Frontier in Heat and Mass Transfer, 10(34), 1-7.

Monteccuco A., Siviter J., Knox A.R., 2014, The effect of temperature mismatch on thermoelectric generators electrically connected in series and parallel, Applied Energy, 123, 47-54.

Paraskevas A., Koutroulis E., 2016, A simple maximum power point tracker for thermoelectric generators, Energy Conversion and Management, 108, 355-365.

Ramdhani M., 2005, Rangkaian listrik, Jurusan Teknik Elektro, STT Telkom Bandung, Indonesia.

Remeli M.F., Kiatbodin L., Singh B., Verojporen K., Date A., Akbarzadeh A., 2015, Power generation from waste heat using heat pipe and thermoelectric generator, Energy Procedia, 75, 645-650.

Sugiyanto, Siswantoro S., 2014, Pemanfaatan panas pada kompor gas LPG untuk pembangkitan energi listrik menggunakan generator thermoelektrik, Jurnal Teknologi, 7(2), 100-105.

Sugiyanto S., Umam M.T.N., Suciawan E., 2015, Rancang bangun kontruksi TEG (thermoelectric generator) pada knalpot sepeda motor untuk pembangkitan listrik mandiri, Forum Teknik, 36(1), 56-63.

Suryanto N., Aziz A., Mainil R.I., 2017, Pengujian thermoelectric generator (TEG) dengan sumber kalor electric heater $60 \mathrm{v}$ menggunakan air pendingin pada temperatur lingkungan, Jom FTEKNIK, 4(2), 1-5.

Tang Z.B., Deng Y.D., Su C.Q., Shuai W.W., Xie C.J., 2017, A research on thermoelectric generator's electrical performance under temperature mismatch conditions for automotive waste heat recovery system, Case Studies in Thermal Engineering, 5, 143-150. 